\title{
Toxicological Parameters of Albino Rats Fed with Amarantus hybridus Grown on Crude Oil Post-remediated Agricultural Soil
}

\author{
Eugene N Onyeike, Reginald C Ohiri*, and Augustine A Uwakw \\ Department of Biochemistry, Faculty of Chemical Sciences, College of Natural and Applied Sciences, University of Port Harcourt, Nigeria
}

\begin{abstract}
Hydrocarbon and heavy metal accumulation in Amarantus hybridus grown on crude oil post-remediated soil and its effect on the toxicological indices of Wistar albino rats was carried out. Eighteen square metre farmland was divided into three sites (A, B, C) of 4 $\mathrm{m} 2$ each and $2 \mathrm{~m}$ space was allowed in between the three sites. Two out of the 3 sites were polluted, bioremediated for 16 weeks and healthy seedling of Amarantus hybridus were planted on the three sites. The vegetables were grown for 28 days and their healthy leaves were harvested. The highest growth rate was observed in Amarantus hybridus grown on the bioaugmented soil for 4 weeks with values of $107.20 \pm 12.25 \mathrm{~cm}, 61.69 \pm 2.32 \mathrm{~cm}, 1.72 \pm 0.31 \mathrm{~g}$ and $0.37 \pm 0.02 \mathrm{~g}$ for height, leaf area, fresh weight and dry weight respectively. Amarantus hybridus leaves from natural attenuated soil had the highest aliphatic hydrocarbon, polycyclic aromatic hydrocarbon and heavy metal with values of $9.78 \pm 0.04 \mathrm{mgkg}-1,7.43 \pm 0.09 \mathrm{mgkg}-1$ and $0.08 \pm 0.00 \mathrm{~g} / 100 \mathrm{~g}$ for $\mathrm{C} 29$, Benzo( $\alpha$ )pyrene and Lead respectively. Thirty six healthy Wistar albino rats divided into 4 groups of 9 rats each (adult male, adult female, wealing male and wealing female) and sub-grouped into 3 were acclimatized for one week and fed with formulated feed pellet of $50 \%$ dry weight of Amarantus hybridus, from each of the three lots for 28 days. Assay of the toxicological indices of the test animals showed elevated concentrations of urea, creatinine, alkaline phosphatase, alanine and aspartate aminotransferases, while a slight increase in amylase activity was observed in the animal. Packed Cell Volume (PCV) and haemoglobin concentration of the test animals decreased. These results were authenticated by the histological analysis of the liver, kidney and pancreas sections.
\end{abstract}

Keywords: Bioaccumulation; Bioremediation; Hydrocarbon; Ingestion; Pollution; Toxicity

\section{Introduction}

Industrial revolution brought increasing pressure on soil as a source of raw materials demanded by commerce, while the development of quantitative science offered new opportunities for improved soil management [1]. This inquiry has expanded to an understanding of soil as a complex, dynamic, biogeochemical system that is vital to the life cycle of terrestrial vegetation and soil-inhabiting organisms and by extension to the human race as well. The presence of substances in the soil that are not naturally produced by biological species are of great public concern. Many of these chemicals have been found to be carcinogenic and may accumulate in the environment thereby eliciting toxic effect on the ecosystem. The concentration of toxic compounds in the soil increased dramatically due to the accelerated rate of extraction of minerals and fossil fuels and by highly technological industrial processes [1]. Notable among these extractable toxic fossil fuels are the petroleum hydrocarbons.

Petroleum hydrocarbons are composed of various portions of alkanes (e.g. methane, ethane, etc), aromatics (e.g. benzene, toluene, ethylene and xylene, collectively known as BTEX) and polycyclic aromatics hydrocarbons (PAHs) (e.g. naphthalene, phenanthrene, anthracene, benzo( $\alpha$ )pyrene, etc). Also present in petroleum mixture are organometallo constituents most notably complexing Vanadium and Nickel [2]. Major petroleum fractions consist of a wide range of hydrocarbons from light gases $\left(\mathrm{C}_{1}-\mathrm{C}_{4}\right)$ to heavy residues $\left(\mathrm{C}_{35}-\mathrm{C}_{40}\right)$ [3]. Petroleum-originating volatile organic carbons, especially BTEX compounds (benzene, toluene, $\mathrm{O}$-xylene and $\mathrm{P}$-xylene), are classified as hazardous environmental priority pollutants [2]. In high concentrations, these hydrocarbons molecules are highly toxic to many organisms, including humans [4]. The dominance of petroleum products in the world economy creates the conditions for distributing large amounts of these toxicants into populated areas and ecosystem around the globe [5]. Industrial activities release substantial amount of crude oil and refined products into the environment as a result of accidents such as storage tank leakage, oil spills during routine transportation and shipping operations or sabotage [6]. The contaminant load of soil and water is growing steadily each year in parallel with increasing industrialization and energy demand and therefore necessitate the need for remediation. Different clean-up method has been used for the remediation of crude oil polluted soil. However, Ijah and Antai (2003) [7], reported the ability of chicken drop microorganisms in petroleum hydrocarbon remediation and they identified species of Micrococcus, Bacillus, Pseudomonas, Enterobacter, Proteus, Aspergillus, Rhizopus, Pseudomonas aeruginosa CDB-06 and Penicillium CDF-10 as potential crude oil degraders. Ohiri et al. [8], also reported that the application of chicken drops in bioaugmentation of crude oil polluted site raised the $\mathrm{pH}$ of the top soil to a range 6.89 to 7.80 which favours the growth of soil microorganisms thereby enhancing bioremediation. Resistance of recalcitrant hydrocarbons to degradation is thought to result from the increase in complexity of the molecular structures of branched compounds e.g. Pristane and Phytane relative to linear alkanes [9-11].

Soils subjected to petroleum hydrocarbon bioremediation are used for crop growth without possible consideration to the concentration of the recalcitrant hydrocarbons in the remediated soil. These hydrocarbons can be absorbed by these crops, which may accumulate and even convert them to a more or a less toxic intermediates that are stored in specialized plant cells. The level of photosynthesis in leafy vegetables makes them rich in protein, minerals and sugar [12]. For example, Amarantus hybridus (African spinach) is a perennial vegetable consumed mainly in the oil rich Niger-delta area of Nigeria where

*Corresponding author: Reginald C Ohiri, Department of Biochemistry, Faculty of Chemical Sciences, College of Natural and Applied Sciences, University of Port Harcourt, P. M. B. 5323 East-West Road, Choba, Rivers State, Nigeria, Tel: +234 8038808077; E-mail: raycohiri@yahoo.com

Received October 19, 2014; Accepted November 26, 2014; Published November 28,2014

Citation: Onyeike EN, Ohiri RC, Uwakw AA (2014) Toxicological Parameters of Albino Rats Fed with Amarantus hybridus Grown on Crude Oil Post-remediated Agricultural Soil. J Environ Anal Toxicol 5: 251. doi: 10.4172/2161-0525.1000251

Copyright: (๑) 2014 Onyeike EN, This is an open-access article distributed under the terms of the Creative Commons Attribution License, which permits unrestricted use, distribution, and reproduction in any medium, provided the original author and source are credited. 
it is prominent in soups, yam and plantain meals because of its high vitamin content and other nutritional values. Stored hydrocarbons and its intermediates in plants such as Amarantus hybridus are absorbed by animals and even humans upon the ingestion of the crop produce and thus elicit changes in some biochemical, haematological and histopathological indices of such animals if not properly metabolized and excreted. These parameters will be used in this research to determine the level of toxicity of plant absorbed hydrocarbons on Wistar albino rats.

\section{Materials and Methods}

\section{Sources of materials}

Bonny light crude oil was obtained from Shell Petroleum Development Company (SPDC) flow station at Egbema, Imo State, Nigeria. Chicken drops (40 kg) were purchased from Godvine poultry farm, Eliozu, Obio Akpor, and Rivers State, Nigeria. Healthy seedlings of Amarantus hybridus were purchased from Rumuokoro market, Obio Akpor, Rivers State, Nigeria. Thirty six (36) healthy Wistar albino rats (Ratus ratus) made up of 9 adult males, 9 adult females, 9 weanling males and 9 weanling females were obtained from the Animal House of Department of Biochemistry, University of Port Harcourt, Choba, and River State, Nigeria. Reagent kits for determination of alkaline phosphatase, alanine aminotransferase, aspartate aminotransferase, urea and creatinine concentrations were obtained from Randox lab Ltd, Antrim UK, while kit for determination of alpha amylase was obtained from Giesse Diagnostics, Rome Italy.

\section{Study area}

The study area was located along Eneka-Oyigbo new link road (longitude $7^{\circ} 10^{\prime \prime} \mathrm{E}$ and latitude $4^{\circ} 40^{\prime \prime} \mathrm{N}$ ) in Obio Akpor, Rivers State, Nigeria. The soil of this area belongs to the ultisols. Approximately the entire area consisted of deep uniform sand and clay sand, with slightly humus topsoil and a topsoil $\mathrm{pH}$ of approximately $4.86 \pm 0.12$. There was no record of oil spillage or pipeline vandalization in the area.

\section{Pollution and bioremediation of research site}

Eighteen square metre farmland was divided into three sites (A, $\mathrm{B}, \mathrm{C})$ of $4 \mathrm{~m}^{2}$ each and $2 \mathrm{~m}$ space was allowed in between the three sites. Two of the three sites were polluted, bioremediated and labelled as follows: $\mathrm{B}=4 \mathrm{~m}^{2}$ farmland with $40 \mathrm{dm}^{3}$ of bonny light crude oil to which $40 \mathrm{~kg}$ of chicken drops was added (Bioaugmented soil). $\mathrm{C}=4$ $\mathrm{m}^{2}$ farmland with $40 \mathrm{dm}^{3}$ of bonny light crude oil (Natural attenuated soil), while the unpolluted $4 \mathrm{~m}^{2}$ farmland (control soil) was labelled A.

\section{Planting, determination of growth rate and collection of vegetables samples}

Healthy seedlings of Amarantus hybridus (African spinach), were planted by the method of Nichols and Hilmi (2009) [13] on the three sites and allowed to grow for 28 weeks. Growth rates of the vegetables were determined weekly for four weeks using the simple and nondestructive technique of Wood and Roger (2000) [14]. Plant leaves were collected at the fourth week after planting with an unused sterilized razor blade into sterilized plastic bags sealed with rubber bands. All samples were labelled with a permanent water-resistance marker and were taken to the laboratory within 1 hour of collection for analysis.

\section{Determination of aliphatic hydrocarbons, polycyclic aromatic} hydrocarbons (PAH) and heavy metals

Aliphatic and polycyclic aromatic hydrocarbon concentrations in
Amarantus hybridus were extracted and determined using the method of Association of Official Analytical Chemist (AOAC), (2006), while Heavy metal content was determined by the emission spectroscopy method of Jones Jr.

\section{Formulation of animal feed}

Dry Amarantus hybridus leaves was weighed on a Mettler Toledo AB204 electronic weighing balance, ground in a Thomas Scientific Model 4 Wiley's mill, formed into vegetable pellets and integrated into normal rat feed.

\section{Acclimatization, treatment and sacrificing of experimental animals}

Thirty six (36) Wistar albino rats made up of 9 adult males, 9 adult females, 9 weanling males and 9 weanling females were used for this study. Each group was divided into subgroups of 3 rats each. All the test and control animals were housed at room temperature in stainless steel animal cages with free access to drinking water and standard laboratory animal diets (vital feed) for 1 week of acclimatization. Each sub-group was fed with formulated feed pellet of $50 \%$ dry weight of Amarantus hybridus from the control, bioaugmented and natural attenuated sites each for a period of 28 days. The test and control animals were sacrificed under chloroform anaesthesia and blood was collected through cardiac puncture. The blood was stored in ethylene diamine tetraacetic acid (EDTA) sample containers for the following analysis alkaline phosphate (ALP), aspartate aminotransferase (AST), alanine aminotransferase (ALT), urea, creatinine, amylase, packed cell volume (PCV) and haemoglobin concentrations. The liver, kidney and pancreas were quickly dissected out and placed into containers containing $10 \%$ physiological saline as preservative. These samples were taken to the laboratory within 1 hour of collection for analysis.

\section{Determination of toxicological parameters of experimental animals}

Serum urea concentration was determined by the diacetyl monoxine method (DAM) of Beale RN, Croft D (1961) [15], creatinine concentration was determined by the Alkaline Picric acid method of Slot (1965) [16], while serum amylase activity and ALP activity were determined by the 2-chloro-p-nitrophenyl- $\alpha$-D-maltotrioside (CNPG3) kinetic method of Hohenwallner et al. (1979) [17] and the method of Kind and King (1954) [18], respectively. AST and ALT activities were determined by the Colourimetric end-point method of Reitman and Frankel (1957) [19]. Packed cell volume (PCV) and haemoglobin concentration were determined by the method Corash 1995 [20], while histological analysis of rat tissues was carried out using the method of Conn (1969) [21].

\section{Statistical analysis}

The mean \pm standard deviations and One Way Analysis of Variance (ANOVA) were calculated electronically using International Business Machine (IBM) Statistical Program for Social Sciences (SPSS) 19 statistics software (SPSS Inc Chicago) at 95\% confidence level, using post hoc Duncan (1955) [22], multiple range test of significance.

\section{Results}

\section{Growth rate of Amarantus hybridus}

The growth rates of Amarantus hybridus grown on crude oil bioremediated soil are embodied in Table 1. In all the sites (control, natural attenuated and bioaugmented sites), heights, leaf areas, fresh 


\begin{tabular}{|c|c|c|c|c|c|c|c|c|c|c|c|c|}
\hline & & Heights (cm) & & & $\begin{array}{l}\text { Leaf area } \\
\left(\mathrm{cm}^{2}\right)\end{array}$ & & & $\begin{array}{l}\text { Fresh } \\
\text { weights (g) }\end{array}$ & & & $\begin{array}{l}\text { Dry weights } \\
\text { (g) }\end{array}$ & \\
\hline & Control soil & $\begin{array}{l}\text { Natural } \\
\text { attenuated } \\
\text { soil }\end{array}$ & $\begin{array}{l}\text { Bioaugmented } \\
\text { soil }\end{array}$ & Control soil & $\begin{array}{l}\text { Natural } \\
\text { attenuated } \\
\text { soil }\end{array}$ & $\begin{array}{l}\text { Bioaugmented } \\
\text { soil }\end{array}$ & Control soil & $\begin{array}{l}\text { Natural } \\
\text { attenuated } \\
\text { soil }\end{array}$ & $\begin{array}{l}\text { Bioaugmented } \\
\text { soil }\end{array}$ & Control soil & $\begin{array}{l}\text { Natural } \\
\text { attenuated } \\
\text { soil }\end{array}$ & $\begin{array}{l}\text { Bioaugmented } \\
\text { soil }\end{array}$ \\
\hline Week 1 & $8.33 \pm 2.2^{\mathrm{ac}}$ & $9.50 \pm 1.04^{\mathrm{ac}}$ & $15.50 \pm 1.80^{b}$ & $4.30 \pm 0.96^{a}$ & $16.83 \pm 2.57^{\mathrm{bc}}$ & $16.17 \pm 3.34^{\mathrm{bc}}$ & $0.12 \pm 0.02^{\mathrm{ac}}$ & $0.32 \pm 0.06^{a c}$ & $0.91 \pm 0.15^{b}$ & $0.01 \pm 0.00^{\mathrm{a}}$ & $0.07 \pm 0.01^{\circ}$ & $0.10 \pm 0.00^{\mathrm{b}}$ \\
\hline Week 2 & $12.27 \pm 2.02^{\mathrm{a}}$ & $20.97 \pm 2.05^{c}$ & $40.63 \pm 4.27^{b}$ & $7.33 \pm 1.33^{\mathrm{a}}$ & $25.40 \pm 2.57^{c}$ & $40.34 \pm 3.22^{b}$ & $0.16 \pm 0.04^{\mathrm{a}}$ & $0.61 \pm 0.08^{c}$ & $1.34 \pm 0.09^{b}$ & $0.03 \pm 0.01^{\mathrm{a}}$ & $0.12 \pm 0.01^{\mathrm{c}}$ & $0.24 \pm 0.02^{b}$ \\
\hline Week 3 & $17.70 \pm 1.90^{\mathrm{a}}$ & $33.43 \pm 1.21^{c}$ & $65.67 \pm 4.92^{\mathrm{b}}$ & $16.00 \pm 3.46^{\mathrm{a}}$ & $30.07 \pm 3.64^{c}$ & $56.43 \pm 1.25^{\mathrm{b}}$ & $0.49 \pm 0.10^{\text {ac }}$ & $1.11 \pm 0.35^{\mathrm{ac}}$ & $1.19 \pm 0.20^{\mathrm{b}}$ & $0.05 \pm 0.04^{a}$ & $0.17 \pm 0.02^{\mathrm{c}}$ & $0.31 \pm 0.03^{b}$ \\
\hline Week 4 & $42.20 \pm 5.38^{\mathrm{a}}$ & $76.07 \pm 5.86^{c}$ & $107.20 \pm 12.25^{b}$ & $17.67 \pm 2.89^{\mathrm{a}}$ & $34.13 \pm 3.78^{c}$ & $61.69 \pm 2.32^{b}$ & $0.63 \pm 0.02^{\mathrm{ac}}$ & $0.98 \pm 0.26^{\mathrm{ac}}$ & $1.72 \pm 0.31^{b}$ & $0.07 \pm 0.01^{\mathrm{a}}$ & $0.22 \pm 0.01^{\circ}$ & $0.37 \pm 0.02^{\mathrm{b}}$ \\
\hline
\end{tabular}

Values are Means \pm standard deviations of triplicate determinations. Values in each row with different superscript letters differ significantly at $5 \%$ level (P < 0.05$)$.

Table 1: Growth rate of Amarantus hybridus grown on crude oil post-remediated soil.

and dry weights increased from week 1 to week 4 . The increase in growth parameters was highest in Amarantus hybridus grown on bioaugmented soil followed by natural attenuated soil and was lowest in the control soil.

\section{Hydrocarbon and heavy metal content of vegetable samples}

The mean concentration of aliphatic hydrocarbons, polycyclic aromatic hydrocarbons and heavy metals in Amarantus hybridus grown on the control, natural attenuated and bioaugmented soil is presented in Tables 2-4. The concentration of aliphatic hydrocarbons in Amarantus hybridus grown on both the natural attenuated and bioaugmented soils were significantly $(\mathrm{P}<0.05)$ higher than in those grown on the control, except for C14, where a higher concentration was observed in the control. Polycyclic aromatic hydrocarbon content of Amarantus hybridus also increased significantly $(\mathrm{P}<0.05)$ in those grown on the natural attenuated and bioaugmented soil except for chrysene where a higher value of $1.85 \mathrm{mgkg}^{-1}$ was observed in those grown on the control, while those grown on the bioaugmented soil had $1.23 \mathrm{mgkg}^{-1}$. Fluorene was absent in Amarantus hybridus grown on control but present in those grown on both the natural attenuated and bioaugmented soil, while Naphthalene, acenaphthylene, pyrene, benzo(k)fluoranthene and benzo(g,h,i)perylene were not observed in all the samples. Though only copper was dictated in Amarantus hybridus grown on the control, the heavy metal concentration in those grown on the bioaugmented soil were significantly $(\mathrm{P}<0.05)$ higher than those grown on the natural attenuated soil.

\section{Markers of tissue damage and haematological parameters}

The mean concentrations of urea, creatinine, amylase, alkaline phosphate (ALP), aspartate aminotransferase (AST), alanine aminotransferase (ALT), packed cell volume (PCV) and haemoglobin in rats fed with Amarantus hybridus grown on the control, natural attenuated and bioaugmented soil are presented in Tables 5-12. The urea, creatinine, amylase, alkaline phosphatase, alanine and aspartate aminotransferases increased significantly $(\mathrm{P}<0.05)$ in rats fed with Amarantus hybridus grown on the natural attenuated and bioaugmented soil. The packed cell volume (PCV) and haemoglobin concentrations decreased significantly $(\mathrm{P}<0.05)$ in all the rats fed with Amarantus hybridus grown on the natural attenuated and bioaugmented soil. The decrease in packed cell volume and haemoglobin concentration were more pronounced in rats fed with Amarantus hybridus grown on bioaugmented soil than in those fed with Amarantus hybridus grown on the natural attenuated soil.

\section{Histology sections of rats fed with Amarantus hybridus grown on crude oil post-remediated soil}

Histology sections of rats fed with Amarantus hybridus grown on crude oil post-remediated soil are shown in Figures 1-9. Kidney sections of rats fed with Amarantus hybridus grown on the control soil showed healthy kidney with perfect glomeruli structures and tissue architecture (Figure 1); while kidney sections of rats fed with Amarantus hybridus grown on both the natural attenuated and bioaugmented soil showed unhealthy organ with shrunken glomeruli, multicystic spaces and completely distorted tissue architecture (Figures 2 and 3).

Rats fed with Amarantus hybridus grown on the control soil had health liver with clearly identified hepatocytes and central vein (Figure 4). Scanty stroma and tissue proliferation around the central veins were observed in the liver sections of rats fed with Amarantus hybridus grown on the natural attenuated soil (Figure 5), while blocked central vein with tissue proliferation and distorted tissue architecture were observed in rats fed with Amarantus hybridus grown on bioaugmented the soil (Figure 6).

The pancreas sections of rats fed with Amarantus hybridus grown on control soil had healthy and undistorted pancreas (Figure 7), while those fed with Amarantus hybridus grown on both the natural attenuated and bioaugmented soil showed distorted tissue architecture with scanty stroma and mild oedema (Figures 8 and 9).

\section{Discussion}

The result of this study showed increase in height, fresh weight, dry weight, and leaf surface area of Amarantus hybridus grown on bioaugmented soil as compared to those grown on both the natural attenuated and control soil (Table 1). This increase in growth may be attributed to the availability of nutrients (in form of chicken drops) added to the bioaugmented soil. This agrees with the work of Ijah and Antai [7], which reported that chicken drops has $2.3 \%$ total nitrogen, $0.5 \%$ available phosphorus and $18.5 \%$ moisture content in addition to other nutrients. Moverever, Ohiri et al. [8] also reported the ability of chicken drops to buffers the $\mathrm{pH}$ of crude oil bioaugmented soil to a range of 6.89 to 7.90 , which may also favour the growth of Amarantus hybridus. The increase in growth of vegetables grown on the natural attenuated soil as compared to the control soil may be attributed to increased nitrogen concentration caused by the death and degradation of non-petroleum degrading microorganism and other soil organisms thus increasing the nutrient level of the soil. Vegetables (such as Amarantus hybridus) also contain high level of antioxidant vitamins, which may be used in the mopping up of free radicals generated through degradation of plant accumulated hydrocarbons thereby allowing the growth of such vegetables as observed in this study.

The pronounced increase in aliphatic hydrocarbon concentration observed in Amarantus hybridus leaves after 4 weeks of growth on the natural attenuated and bioaugmented soil (Table 2) may be due to the pollution of these soils with $40 \mathrm{dm}^{3}$ of bonny light crude oil. This tantamount to high concentration of these hydrocarbons in both the natural attenuated and bioaugmented soil. However, these accumulations are higher in the leaves Amarantus hybridus grown on the natural attenuated soil than those grown on the 
Citation: Onyeike EN, Ohiri RC, Uwakw AA (2014) Toxicological Parameters of Albino Rats Fed with Amarantus hybridus Grown on Crude Oil Postremediated Agricultural Soil. J Environ Anal Toxicol 4: 251. doi: 10.4172/2161-0525.1000251

Page 4 of 8

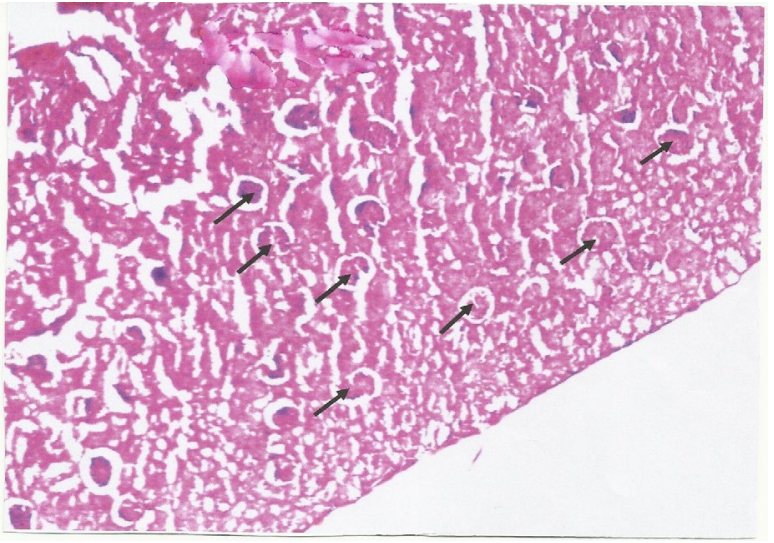

Figure1: Kidney section of rat fed with Amarantus hybridus grown on the control soil. (Magnification: X400). Observations: Glomeruli perfectly in order (Black arrows). No observable change.

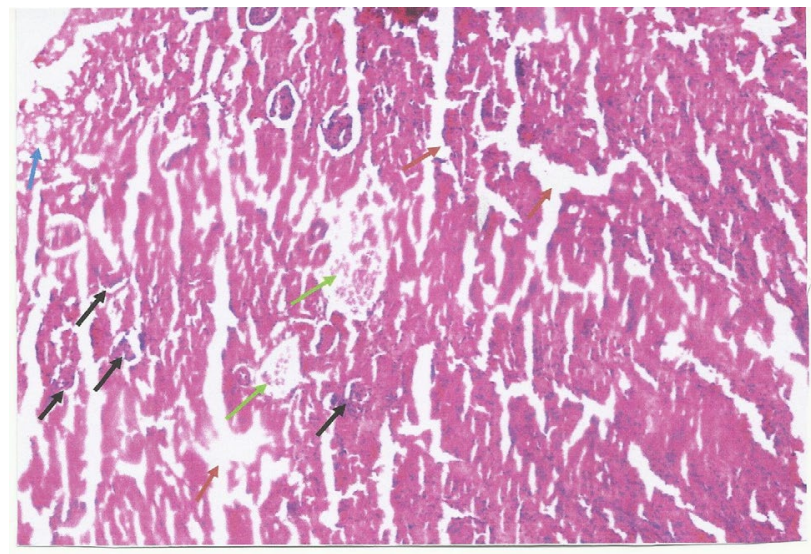

Figure 2: Kidney section of rat fed with Amarantus hybridus grown on the natural attenuated soil.

(Magnification: X400).

Observations: Glomeruli shrunken in some areas (Black arrows). Scanty stroma with multicystic spaces (Blue arrows). Distorted tissue architecture (Red arrows). Necrosis (Green arrows).

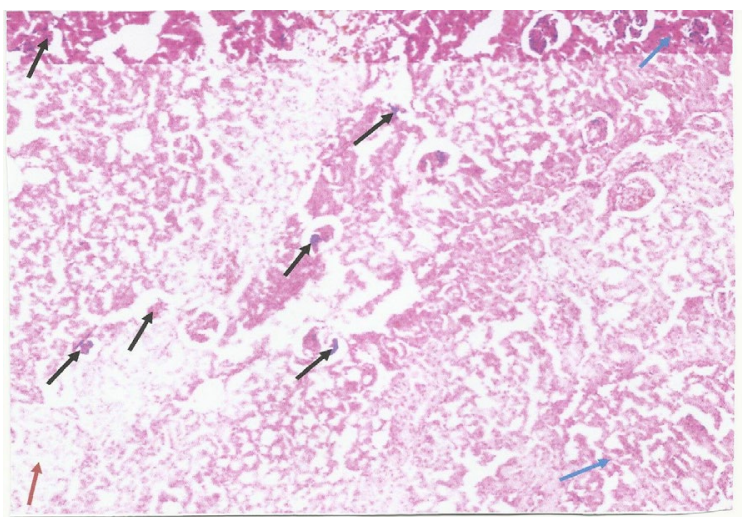

Figure 3: Kidney section of rat fed with Amarantus hybridus grown on the bioaugmented soil. (Magnification: X400).

Observations: Glomeruli shrunken (Black arrows) Oedema (Blue arrows). Tissue proliferation (Red arrows) bioaugmented and the control soil. This variation may be attributed to the low concentration of nutrients in the natural attenuated soil. Foliar accumulation of aliphatic hydrocarbons has been reported in many plants [23]. This present finding corroborates the work of Kipopoulou et al. [23], where aliphatic hydrocarbons were observed in the inner tissues of different vegetable species grown in the greater industrial area of Thessaloniki, Northern Greece. The presence of aliphatic hydrocarbon observed in leaves of Amarantus hybridus grown on the control (Table 2). May be attributed to horizontal flow or trans-boundary transfer of crude oil hydrocarbons. This study also showed a pronounced increase in polycyclic aromatic hydrocarbon concentration in leaves of Amarantus hybridus grown for four weeks on the natural attenuated, bioaugmented and the control soil (Table 3). This may be due to the uptake of these aromatic hydrocarbons by the plant roots and subsequent accumulation in the foliar parts of the vegetable. This corroborates the work of Tao et al. [24], where all the polycyclic aromatic hydrocarbon present in agricultural soil from Tianjin China was detected in the aerial parts of the vegetables planted in those soil, suggesting foliar uptake as the primary transfer pathway of polycyclic aromatic hydrocarbons from the rhizosphere to the vegetables. The increase in heavy metal content observed in Amarantus hybridus grown on the natural attenuated and bioaugmented soil may also be attributed to the presence of these metals in the crude oil (Table 4). This agrees with the work of Chicarelli et al. [25], which reported that heavy metal such as copper and nickel are found in crude via their association with porphyrins. However, not all contaminants are easily treated by bioremediation using microorganisms. For example, heavy metals such as Cadmium and Lead are not readily absorbed by microorganisms [26]. Phytoremediation has proved useful in this area and this may be responsible for the absorption and accumulation of heavy metals by Amarantus hybridus grown on the natural attenuated and bioaugmented soil (Table 4).

The pronounced increase in the toxicological parameters observed in rats fed with vegetables grown on the natural attenuated and bioaugmented soil (except for serum amylase where slight increase was observed) can be attributed to the biotransformation activities and renal excretion processes of the liver and kidneys respectively (Tables 5-10). Renal excretion of toxicants has been greatly associated with the kidney. However, in the cause of excretion, lipid soluble substances (such as aliphatic petroleum hydrocarbons and polycyclic aromatic hydrocarbons) are readily reabsorbed in the renal tubule. This may lead to accumulation of these toxicants in the kidneys and subsequent destruction of kidney cells (Figures 1-3). This destruction may cause elevations of urea and creatinine concentrations as observed in the serum of rats fed with Amarantus hybridus grown on bioaugmented and natural attenuated sites (Tables 5 and 6 ). Though some heavy metals such as copper and selenium are involved in body metabolism, in high concentrations they can also be toxic [27]. For example, exposure to high concentration of cadmium is associated with renal dysfunction, obstructive lung disease, lung cancer and bone defects (osteomalacia, osteoporosis) in humans and animals, while long-term exposure to high concentrations of chromium causes kidney and liver damage, and also destroys the circulatory and nerve tissues [27]. Copper is essential to human life, but in high doses, it has been reported to cause anaemia, liver and kidney damage, and gastro intestinal irritation [27]. These heavy metal toxicities may have contributed to the elevated concentrations of the toxicological parameters as observed in rats fed with vegetables grown on bioaugmented and natural attenuated soil (Tables 5-12). The pancreas does not filter or take part in biotransformation rather; it synthesizes enzymes that enhance degradation of substances in the 
Citation: Onyeike EN, Ohiri RC, Uwakw AA (2014) Toxicological Parameters of Albino Rats Fed with Amarantus hybridus Grown on Crude Oil Postremediated Agricultural Soil. J Environ Anal Toxicol 4: 251. doi: 10.4172/2161-0525.1000251

Page 5 of 8

\begin{tabular}{|c|c|c|c|}
\hline & Control soil & Natural attenuated soil & Bioaugmented soil \\
\hline $\mathrm{C}_{8}$ & $2.02 \pm 0.01^{a}$ & $7.97 \pm 0.32^{b}$ & $3.62 \pm 0.29^{c}$ \\
\hline $\mathrm{C}_{9}$ & $1.10 \pm 0.03^{\mathrm{a}}$ & $1.24 \pm 0.01^{b}$ & $8.54 \pm 0.01^{\circ}$ \\
\hline $\mathrm{C}_{10}$ & $1.07 \pm 0.00^{\mathrm{abc}}$ & $1.07 \pm 0.02^{\mathrm{abc}}$ & $1.08 \pm 0.00^{\mathrm{abc}}$ \\
\hline$C_{11}$ & $1.63 \pm 0.02^{\mathrm{a}}$ & $7.52 \pm 0.04^{b}$ & $2.09 \pm 0.02^{c}$ \\
\hline $\mathrm{C}_{12}$ & $2.23 \pm 0.04^{a c}$ & $8.64 \pm 0.19^{b}$ & $2.47 \pm 0.04^{\mathrm{ac}}$ \\
\hline $\mathrm{C}_{13}$ & $1.08 \pm 0.02^{\mathrm{a}}$ & $4.78 \pm 0.05^{b}$ & $1.61 \pm 0.00^{\circ}$ \\
\hline $\mathrm{C}_{14}$ & $2.45 \pm 0.12^{\mathrm{a}}$ & $1.28 \pm 0.04^{\mathrm{bc}}$ & $1.12 \pm 0.01^{\mathrm{bc}}$ \\
\hline $\mathrm{C}_{15}$ & $1.06 \pm 0.02^{\mathrm{a}}$ & $1.60 \pm 0.02^{b}$ & $7.44 \pm 0.03^{c}$ \\
\hline $\mathrm{C}_{16}$ & $2.34 \pm 0.06^{a c}$ & $6.64 \pm 0.01^{\mathrm{b}}$ & $2.35 \pm 0.18^{\mathrm{ac}}$ \\
\hline$C_{17}$ & $1.38 \pm 0.06^{\mathrm{a}}$ & $4.70 \pm 0.04^{b}$ & $3.75 \pm 0.10^{c}$ \\
\hline Pristane & $1.08 \pm 0.03^{\mathrm{a}}$ & $1.19 \pm 0.01^{\mathrm{b}}$ & $1.98 \pm 0.05^{c}$ \\
\hline $\mathrm{C}_{18}$ & $1.91 \pm 0.16^{\mathrm{a}}$ & $2.74 \pm 0.04^{b}$ & $6.36 \pm 0.08^{c}$ \\
\hline Phytane & $1.68 \pm 0.08^{\mathrm{a}}$ & $4.85 \pm 0.01^{b}$ & $3.00 \pm 0.00^{\circ}$ \\
\hline $\mathrm{C}_{19}$ & $2.77 \pm 0.18^{\mathrm{a}}$ & $2.02 \pm 0.01^{b}$ & $7.19 \pm 0.02^{\mathrm{c}}$ \\
\hline $\mathrm{C}_{20}$ & $3.21 \pm 0.02^{\mathrm{a}}$ & $5.16 \pm 0.08^{b}$ & $7.05 \pm 0.18^{c}$ \\
\hline $\mathrm{C}_{21}$ & $1.77 \pm 0.12^{\mathrm{a}}$ & $3.62 \pm 0.04^{b}$ & $3.31 \pm 0.03^{c}$ \\
\hline $\mathrm{C}_{22}$ & $3.18 \pm 0.03^{\mathrm{a}}$ & $7.93 \pm 0.02^{b}$ & $1.42 \pm 0.05^{c}$ \\
\hline $\mathrm{C}_{23}$ & $2.27 \pm 0.05^{\mathrm{a}}$ & $3.02 \pm 0.04^{b}$ & $2.70 \pm 0.00^{c}$ \\
\hline $\mathrm{C}_{24}$ & $1.07 \pm 0.03^{\mathrm{ab}}$ & $1.05 \pm 0.01^{\mathrm{ab}}$ & $2.77 \pm 0.20^{c}$ \\
\hline $\mathrm{C}_{25}$ & $1.11 \pm 0.02^{\mathrm{a}}$ & $1.46 \pm 0.04^{b}$ & $2.47 \pm 0.06^{c}$ \\
\hline $\mathrm{C}_{26}$ & $3.25 \pm 0.08^{\mathrm{a}}$ & $8.69 \pm 0.05^{b}$ & $1.84 \pm 0.16^{c}$ \\
\hline $\mathrm{C}_{27}$ & $3.93 \pm 0.01^{\mathrm{a}}$ & $6.53 \pm 0.03^{b}$ & $4.60 \pm 0.14^{c}$ \\
\hline $\mathrm{C}_{28}$ & $1.32 \pm 0.04^{a b}$ & $1.54 \pm 0.02^{\mathrm{ab}}$ & $2.82 \pm 0.18^{c}$ \\
\hline $\mathrm{C}_{29}$ & $2.43 \pm 0.05^{\mathrm{a}}$ & $9.78 \pm 0.04^{b}$ & $4.61 \pm 0.25^{c}$ \\
\hline $\mathrm{C}_{30}$ & $1.90 \pm 0.04^{a}$ & $1.46 \pm 0.01^{\mathrm{b}}$ & $8.10 \pm 0.01^{c}$ \\
\hline $\mathrm{C}_{31}$ & $1.94 \pm 0.02^{\mathrm{a}}$ & $8.82 \pm 0.03^{b}$ & $8.21 \pm 0.01^{c}$ \\
\hline $\mathrm{C}_{32}$ & $2.45 \pm 0.01^{a}$ & $7.64 \pm 0.01^{b}$ & $2.41 \pm 0.02^{\mathrm{c}}$ \\
\hline $\mathrm{C}_{33}$ & $1.51 \pm 0.01^{\mathrm{a}}$ & $1.69 \pm 0.03^{b}$ & $4.04 \pm 0.02^{c}$ \\
\hline $\mathrm{C}_{34}$ & $1.75 \pm 0.24^{\mathrm{abc}}$ & $1.87 \pm 0.07^{\mathrm{abc}}$ & $1.92 \pm 0.04^{\mathrm{abc}}$ \\
\hline $\mathrm{C}_{35}$ & $4.06 \pm 0.06^{a}$ & $8.04 \pm 0.01^{b}$ & $5.14 \pm 0.02^{c}$ \\
\hline $\mathrm{C}_{36}$ & $1.51 \pm 0.05^{\mathrm{a}}$ & $3.27 \pm 0.06^{b}$ & $1.01 \pm 0.01^{c}$ \\
\hline $\mathrm{C}_{37}$ & $1.80 \pm 0.05^{a}$ & $2.64 \pm 0.01^{b}$ & $5.28 \pm 0.03^{c}$ \\
\hline $\mathrm{C}_{38}$ & $2.72 \pm 0.03^{a}$ & $3.16 \pm 0.00^{b}$ & $8.15 \pm 0.01^{c}$ \\
\hline $\mathrm{C}_{39}$ & $1.33 \pm 0.02^{\mathrm{a}}$ & $4.25 \pm 0.00^{b}$ & $1.91 \pm 0.01^{c}$ \\
\hline$C_{40}$ & $1.09 \pm 0.06^{\mathrm{a}}$ & $2.95 \pm 0.00^{\mathrm{b}}$ & $4.22 \pm 0.01^{c}$ \\
\hline
\end{tabular}

Values are Means \pm standard deviations of triplicate determinations. Values in each row with different superscript letters differ significantly at $5 \%$ level $(P<0.05)$.

Table 2: Aliphatic hydrocarbon content $\left(\mathrm{mgkg}^{-1}\right)$ of Amarantus hybridus grown on crude oil post-remediated soil

\begin{tabular}{|c|c|c|c|}
\hline $\begin{array}{c}\text { Polycyclic aromatic } \\
\text { hydrocarbon }\end{array}$ & Control soil & $\begin{array}{c}\text { Natural } \\
\text { attenuated soil }\end{array}$ & Bioaugmented soil \\
\hline Naphthalene & ND & ND & ND \\
\hline Acenaphthylene & ND & ND & ND \\
\hline Acenaphthene & $2.73 \pm 0.26^{\mathrm{a}}$ & $4.38 \pm 0.23^{\mathrm{b}}$ & $4.60 \pm 0.09^{\mathrm{c}}$ \\
\hline Fluorene & $\mathrm{ND}$ & $0.78 \pm 0.07^{\mathrm{b}}$ & $1.42 \pm 0.01^{\mathrm{c}}$ \\
\hline Phenanthrene & $1.12 \pm 0.04^{\mathrm{a}}$ & $2.14 \pm 0.28^{\mathrm{b}}$ & $1.60 \pm 0.20^{\mathrm{c}}$ \\
\hline Anthracene & $1.69 \pm 0.16^{\mathrm{a}}$ & $3.63 \pm 0.09^{\mathrm{b}}$ & $3.45 \pm 0.12^{\mathrm{b}}$ \\
\hline Fluoranthene & $1.48 \pm 0.02^{\mathrm{a}}$ & $2.41 \pm 0.15^{\mathrm{b}}$ & $1.69 \pm 0.03^{\mathrm{c}}$ \\
\hline Pyrene & $\mathrm{ND}$ & $\mathrm{ND}$ & $\mathrm{ND}$ \\
\hline Benzo(a)anthracene & $0.84 \pm 0.04^{\mathrm{a}}$ & $5.54 \pm 0.10^{\mathrm{b}}$ & $5.86 \pm 0.15^{\mathrm{c}}$ \\
\hline Chrysene & $1.85 \pm 0.15^{\mathrm{a}}$ & $2.03 \pm 0.05^{\mathrm{b}}$ & $1.23 \pm 0.09^{\mathrm{c}}$ \\
\hline Benzo(ß)fluoranthene & $1.24 \pm 0.06^{\mathrm{a}}$ & $1.55 \pm 0.12^{\mathrm{b}}$ & $1.78 \pm 0.39^{\mathrm{c}}$ \\
\hline Benzo(k)fluoranthene & $\mathrm{ND}$ & $\mathrm{ND}$ & $\mathrm{ND}$ \\
\hline Benzo(a)pyrene & $2.05 \pm 0.06^{\mathrm{a}}$ & $7.43 \pm 0.09^{\mathrm{b}}$ & $6.32 \pm 0.10^{\mathrm{c}}$ \\
\hline Indeno (1,2,3)pyrene & $1.06 \pm 0.02^{\mathrm{a}}$ & $5.97 \pm 0.05^{\mathrm{b}}$ & $5.25 \pm 0.28^{\mathrm{c}}$ \\
\hline Indeno(1,2,3-cd)pyrene & $1.36 \pm 0.03^{\mathrm{a}}$ & $2.22 \pm 0.09^{\mathrm{b}}$ & $1.63 \pm 0.04^{\mathrm{c}}$ \\
\hline Dibenz(a,h)anthracene & $2.48 \pm 0.47^{\mathrm{a}}$ & $6.25 \pm 0.06^{\mathrm{b}}$ & $6.76 \pm 0.69^{\mathrm{c}}$ \\
\hline Benzo(g,h,i)perylene & $\mathrm{ND}$ & $\mathrm{ND}$ & $\mathrm{ND}$ \\
\hline
\end{tabular}

Values are Means \pm standard deviations of triplicate determinations. Values in each row with different superscript letters differ significantly at $5 \%$ level.

Table 3: Polycyclic aromatic hydrocarbon (PAH) content $\left(\mathrm{mgkg}^{-1}\right)$ of Amarantus

hybridus grown on crude oil post-remediated soil.

\begin{tabular}{|c|c|c|c|}
\hline & Control soil & $\begin{array}{c}\text { Natural } \\
\text { attenuated soil }\end{array}$ & Bioaugmented soil \\
\hline Copper & $0.02 \pm 0.00^{\mathrm{ab}}$ & $0.02 \pm 0.00^{\mathrm{ab}}$ & $0.04 \pm 0.01^{\mathrm{c}}$ \\
\hline Lead & ND & $0.08 \pm 0.00^{\mathrm{b}}$ & $0.10 \pm 0.01^{\mathrm{c}}$ \\
\hline Chromium & $\mathrm{ND}$ & $0.04 \pm 0.00^{\mathrm{b}}$ & $0.06 \pm 0.01^{\mathrm{c}}$ \\
\hline Cadmium & $\mathrm{ND}$ & $0.01 \pm 0.00^{\mathrm{b}}$ & $0.02 \pm 0.00^{\mathrm{c}}$ \\
\hline Arsenic & ND & ND & $0.03 \pm 0.00^{\mathrm{c}}$ \\
\hline
\end{tabular}

Values are Means \pm standard deviations of triplicate determinations. Values in each row with different superscript letters differ significantly at $5 \%$ level $(P<0.05)$ Table 4: Heavy metal content $(\mathrm{g} / 100 \mathrm{~g})$ of Amarantus hybridus grown on crude oil post-remediated soil.

Control soil Natural attenuated soil Bioaugmented soil

\begin{tabular}{l|l|l|l} 
Weanling male & $0.92 \pm 0.02^{\mathrm{a}}$ & $1.60 \pm 0.05^{\mathrm{bc}}$ & $1.68 \pm 0.01^{\mathrm{bc}}$
\end{tabular}

\begin{tabular}{l|l|l|l} 
Weanling female & $0.84 \pm 0.04^{\mathrm{a}}$ & $1.57 \pm 0.03^{\mathrm{bc}}$ & $1.61 \pm 0.03^{\mathrm{bc}}$
\end{tabular}

\begin{tabular}{|l|l|l|l}
\hline Adult male & $1.10 \pm 0.03^{\mathrm{a}}$ & $1.50 \pm 0.03^{\mathrm{b}}$ & $1.74 \pm 0.05^{\mathrm{c}}$
\end{tabular}

\begin{tabular}{|l|l|l|l}
\hline Adult female & $0.81 \pm 0.08^{\mathrm{a}}$ & $1.61 \pm 0.08^{\mathrm{b}}$ & $1.80 \pm 0.10^{\mathrm{c}}$
\end{tabular}

Values are Means \pm standard deviations of triplicate determinations. Values in each row with different superscript letters differ significantly at $5 \%$ level $(P<0.05)$ Table 5: Serum urea concentration $\left(\mathrm{mgdl}^{-1}\right)$ of rats fed with Amarantus hybridus grown on crude oil post-remediated soil.

\begin{tabular}{|l|c|l|l|}
\hline & Control soil & Natural attenuated soil & Bioaugmented soil \\
\hline Weanling male & $0.92 \pm 0.02^{\mathrm{a}}$ & $1.60 \pm 0.05^{\mathrm{bc}}$ & $1.68 \pm 0.01^{\mathrm{bc}}$ \\
\hline Weanling female & $0.84 \pm 0.04^{\mathrm{a}}$ & $1.57 \pm 0.03^{\mathrm{bc}}$ & $1.61 \pm 0.03^{\mathrm{bc}}$ \\
\hline Adult male & $1.10 \pm 0.03^{\mathrm{a}}$ & $1.50 \pm 0.03^{\mathrm{b}}$ & $1.74 \pm 0.05^{\mathrm{c}}$ \\
\hline Adult female & $0.81 \pm 0.08^{\mathrm{a}}$ & $1.61 \pm 0.08^{\mathrm{b}}$ & $1.80 \pm 0.10^{\mathrm{c}}$
\end{tabular}

Values are Means \pm standard deviations of triplicate determinations.Values in each row with different superscript letters differ significantly at $5 \%$ level $(P<0.05)$

Table 6: Serum creatinine concentration $\left(\mathrm{mgdl}^{-1}\right)$ of rats fed with Amarantus hybridus grown on crude oil post-remediated soil.

\begin{tabular}{|l|l|l|l|}
\hline & Control soil & Natural attenuated soil & Bioaugmented soil \\
\hline Weanling male & $27.92 \pm 0.57^{\mathrm{abc}}$ & $28.78 \pm 1.15^{\mathrm{abc}}$ & $26.82 \pm 0.40^{\mathrm{abc}}$ \\
\hline Weanling female & $28.07 \pm 0.66^{\mathrm{ab}}$ & $29.94 \pm 0.67^{\mathrm{abc}}$ & $30.92 \pm 1.36^{\mathrm{bc}}$ \\
\hline Adult male & $33.89 \pm 0.20^{\mathrm{ac}}$ & $36.86 \pm 0.77^{\mathrm{b}}$ & $35.23 \pm 0.63^{\mathrm{ac}}$ \\
\hline Adult female & $32.89 \pm 0.35^{\mathrm{a}}$ & $36.10 \pm 0.90^{\mathrm{bc}}$ & $35.72 \pm 1.51^{\mathrm{bc}}$ \\
\hline
\end{tabular}

Values are Means \pm standard deviations of triplicate determinations. Values in each row with different superscript letters differ significantly at $5 \%$ level $(P<0.05)$ Table 7: Serum amylase concentration (I.U. $\left.{ }^{-1}\right)$ of rats fed with Amarantus hybridus grown on crude oil post-remediated soil.

\begin{tabular}{|l|c|c|c|}
\hline & Control soil & Natural attenuated soil & Bioaugmented soil \\
\hline Weanling male & $152.31 \pm 0.41^{\mathrm{a}}$ & $418.37 \pm 0.54^{\mathrm{b}}$ & $474.03 \pm 1.09^{\mathrm{c}}$ \\
\hline Weanling female & $167.02 \pm 1.21^{\mathrm{a}}$ & $422.82 \pm 1.20^{\mathrm{b}}$ & $462.31 \pm 0.90^{\mathrm{c}}$ \\
\hline Adult male & $170.42 \pm 1.88^{\mathrm{a}}$ & $316.58 \pm 0.80^{\mathrm{b}}$ & $446.32 \pm 1.49^{\mathrm{c}}$ \\
\hline Adult female & $224.62 \pm 1.79^{\mathrm{a}}$ & $405.71 \pm 2.10^{\mathrm{b}}$ & $457.19 \pm 5.91^{\mathrm{c}}$ \\
\hline
\end{tabular}

Values are Means \pm standard deviations of triplicate determinations. Values in each row with different superscript letters differ significantly at $5 \%$ level $(P<0.05)$.

Table 8: Serum alkaline phosphatase concentration (I.U.I-1) of rats fed with Amarantus hybridus grown on crude post-remediated oil soil.

\begin{tabular}{|l|c|c|c|}
\hline & Control soil & $\begin{array}{c}\text { Natural } \\
\text { attenuated soil }\end{array}$ & Bioaugmented soil \\
\hline Weanling male & $24.42 \pm 0.80^{\mathrm{a}}$ & $59.58 \pm 0.65^{\mathrm{c}}$ & $62.40 \pm 0.42^{\mathrm{b}}$ \\
\hline Weanling female & $22.22 \pm 0.61^{\mathrm{a}}$ & $57.20 \pm 0.52^{\mathrm{bc}}$ & $57.01 \pm 1.13^{\mathrm{bc}}$ \\
\hline Adult male & $24.12 \pm 0.21^{\mathrm{a}}$ & $53.37 \pm 1.65^{\mathrm{bc}}$ & $53.07 \pm 0.77^{\mathrm{bc}}$ \\
\hline Adult female & $33.54 \pm 0.64^{\mathrm{a}}$ & $60.89 \pm 0.80^{\mathrm{c}}$ & $53.83 \pm 1.19^{\mathrm{b}}$ \\
\hline
\end{tabular}

Values are Means \pm standard deviations of triplicate determinations. Values in each row with different superscript letters differ significantly at $5 \%$ level $(P<0.05)$.

Table 9: Serum aspartate aminotransferase concentration $\left(\right.$ I.U..$\left.^{-1}\right)$ of rats fed with Amarantus hybridus grown on crude oil post-remediated soil. 
Citation: Onyeike EN, Ohiri RC, Uwakw AA (2014) Toxicological Parameters of Albino Rats Fed with Amarantus hybridus Grown on Crude Oil Postremediated Agricultural Soil. J Environ Anal Toxicol 4: 251. doi: 10.4172/2161-0525.1000251

body. The minimal level of amylase (though slightly higher than the control) observed in this study indicates little damage to the cells of the pancreas (Table 7 and Figures 7- 9).

The increase in concentration of alkaline phosphatase (ALP), aspartate aminotransferase (AST) and alanine aminotransferase (ALT) concentrations observed in rats fed with Amarantus hybridus grown on the natural attenuated and bioaugmented soil (Tables 8-10) may be attributed to the activities of the liver resulting in the detoxification and/or bioactivation of toxicants. Some toxicants that are conjugated (e.g. glucuronidation) in the liver are excreted via the biliary system back into the gastro-intestinal tract (GIT) [28]. Once secreted in bile by active transport and excreted from the bile duct into the small intestine, this conjugated toxicants can be subjected to microbial betaglucuronidase activity that can result in regeneration of the parent toxicants that are more lipophilic than the conjugate [28]. The toxicant can now be reabsorbed by the GIT, thereby eliciting an enterohepatic cycle of toxicants in the body [28]. This cycle may subject the liver to stress conditions, thereby damaging the liver cells (Figures 4-6) and increasing the concentration of the liver enzymes in the blood.

The decrease in Packed Cell Volume (PCV) and Haemoglobin concentrations observed in rats fed with vegetables grown on the natural attenuated and bioaugmented soils may be attributed to the destruction of kidney and liver cells, which subsequently leads to reduced erythropoietin release and thus results to anaemia (Tables 11 and 12). Moreover, apart from neurological and developmental abnormalities, exposure to high concentration of lead may result in toxic biochemical effects in humans and animals, which may affect the kidneys, gastrointestinal tract, joints and reproductive system and subsequently impairs haemoglobin synthesis [29]. This may have contributed to the decrease in Packed Cell Volume (PCV) and Haemoglobin concentrations observed in rats fed with vegetables grown on the natural attenuated and bioaugmented soils.

\section{Conclusion}

Accumulation of recalcitrant petroleum hydrocarbons and heavy metals in vegetables (such as Amarantus hybridus) grown on crude oil polluted and remediated soil should be emphasized and their hydrocarbon and heavy metal content must be ascertained before such vegetables can be recommended for both animal and human consumption.

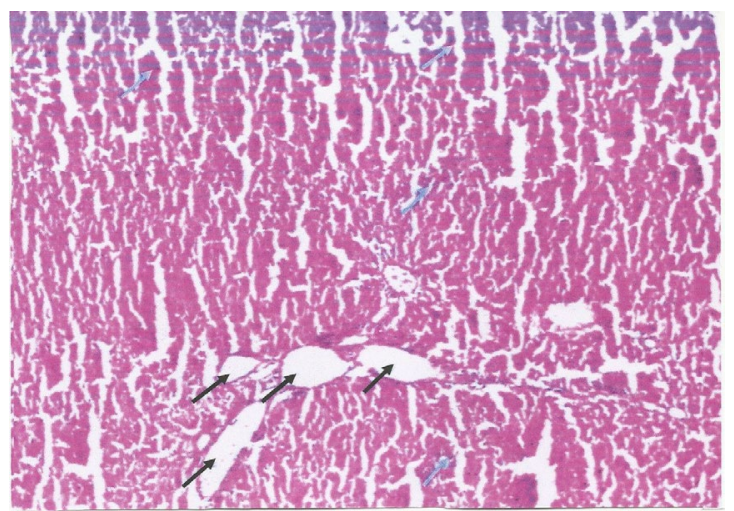

Figure 4: Liver section of rat fed with Amarantus hybridus grown on the control soil. (Magnification: X400).

Observations: Central veins perfectly in order (Black arrows). Hepatocytes clearly identified (Blue arrows). No observable change.

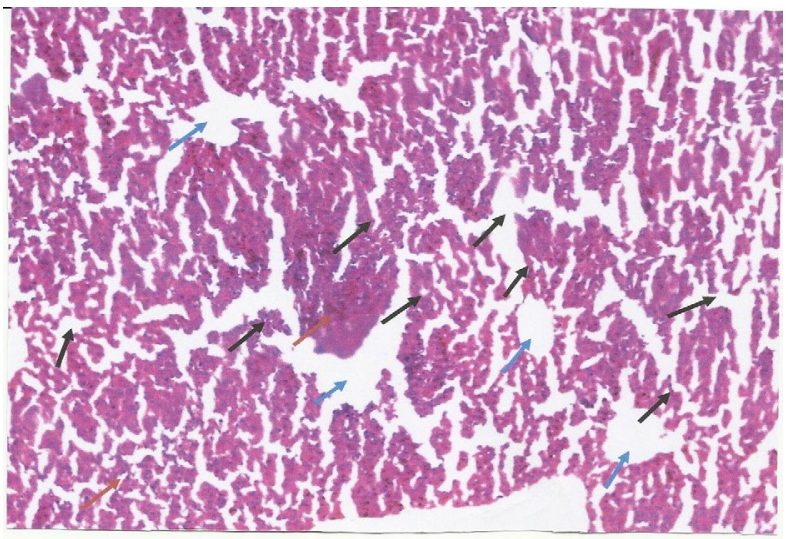

Figure 5: Liver section of rat fed with Amarantus hybridus grown on the natural attenuated soil. (Magnification: X400).

Observations: Scanty stroma (Black arrows). Distorted tissue architecture (Blue arrows). Tissue proliferation (Red arrow).

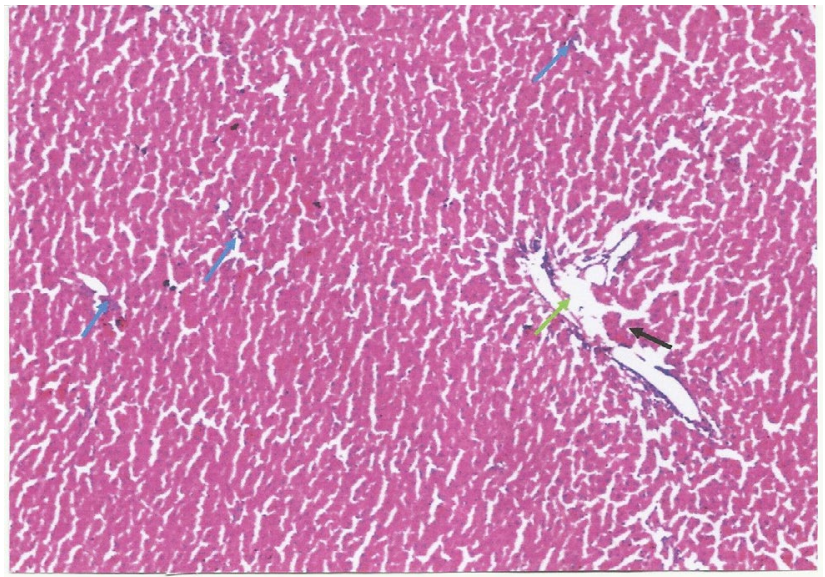

Figure 6: Liver section of rat fed with Amarantus hybridus grown on the bioaugmented soil. (Magnification: X400).

Observations: Tissue proliferation (Black arrow). Central veins almost blocked (Green arrows). Laminae of hepatic cells not in order (Blue arrows).

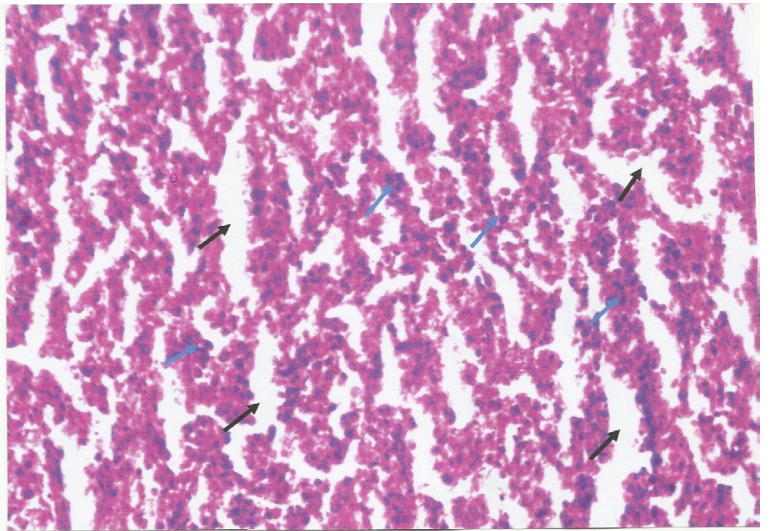

Figure 7: Pancreas section of rat fed with Amarantus hybridus grown on the control soil. (Magnification: X100).

Observations: Mild abrasion (Black arrow). Pancreatic acini clearly observed (Blue arrow 
Citation: Onyeike EN, Ohiri RC, Uwakw AA (2014) Toxicological Parameters of Albino Rats Fed with Amarantus hybridus Grown on Crude Oil Postremediated Agricultural Soil. J Environ Anal Toxicol 4: 251. doi: 10.4172/2161-0525.1000251

Page 7 of 8

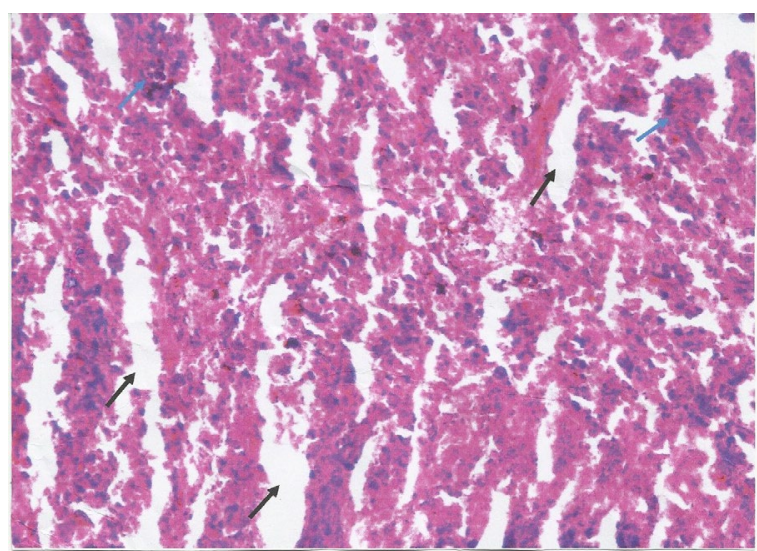

Figure 8: Pancreas section of rat fed with Amarantus hybridus grown on the control soil. (Magnification: X100)

Observations: Stromal abrasions (Black arrow). Mild oedema (Blue arrows)

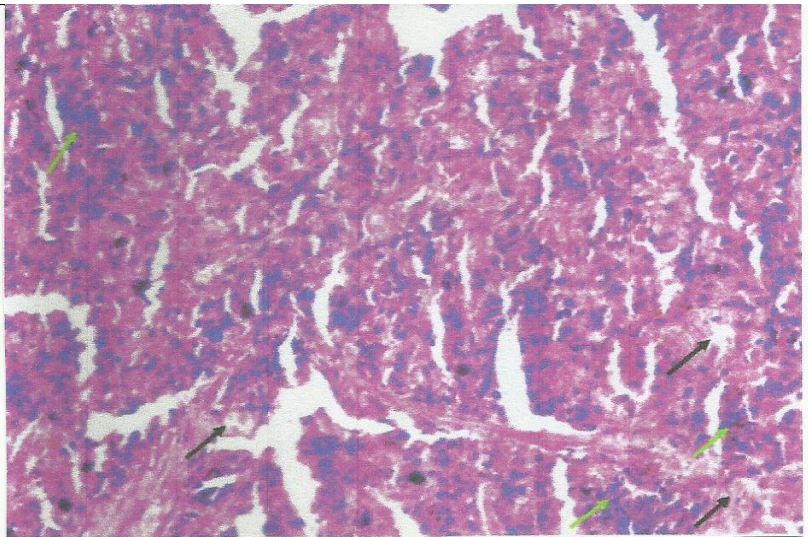

Figure 9: Pancreas section of rat fed with Amarantus hybridus grown on the control soil. (Magnification: X100)

Observations: Necrosis in some areas (Black arrows)

\begin{tabular}{|c|c|c|c|}
\hline & Control soil & $\begin{array}{c}\text { Natural } \\
\text { attenuated soil }\end{array}$ & Bioaugmented soil \\
\hline Weanling male & $20.51 \pm 0.26^{\mathrm{a}}$ & $48.69 \pm 0.31^{\mathrm{c}}$ & $58.08 \pm 0.38^{\mathrm{b}}$ \\
\hline Weanling female & $22.47 \pm 0.78^{\mathrm{a}}$ & $54.77 \pm 2.34^{\mathrm{bc}}$ & $55.00 \pm 0.39^{\mathrm{bc}}$ \\
\hline Adult male & $23.06 \pm 2.16^{\mathrm{a}}$ & $44.04 \pm 1.43^{\mathrm{bc}}$ & $41.31 \pm 0.76^{\mathrm{bc}}$ \\
\hline Adult female & $28.01 \pm 0.37^{\mathrm{a}}$ & $44.11 \pm 0.29^{\mathrm{c}}$ & $46.97 \pm 1.67^{\mathrm{b}}$ \\
\hline
\end{tabular}

Values are Means \pm standard deviations of triplicate determinations. Values in each row with different superscript letters differ significantly at $5 \%$ level $(P<0.05)$.

Table 10: Serum alanine aminotransferase concentration (I.U.I-1) of rats fed with Amarantus hybridus grown on crude oil post-remediated soil.

\begin{tabular}{|l|l|l|l|}
\hline & Control soil & $\begin{array}{l}\text { Natural } \\
\text { attenuated soil }\end{array}$ & Bioaugmented soil \\
\hline Weanling male & $31.00 \pm 1.00^{\mathrm{a}}$ & $23.33 \pm 1.53^{\mathrm{bc}}$ & $21.67 \pm 1.16^{\mathrm{bc}}$ \\
\hline Weanling female & $31.66 \pm 2.08^{\mathrm{a}}$ & $24.69 \pm 2.10^{\mathrm{bc}}$ & $23.76 \pm 2.08^{\mathrm{bc}}$ \\
\hline Adult male & $34.66 \pm 2.52^{\mathrm{a}}$ & $25.33 \pm 0.58^{\mathrm{bc}}$ & $23.67 \pm 2.51^{\mathrm{bc}}$ \\
\hline Adult female & $33.20 \pm 1.73^{\mathrm{a}}$ & $24.66 \pm 2.52^{\mathrm{bc}}$ & $22.33 \pm 1.53^{\mathrm{bc}}$ \\
\hline
\end{tabular}

Values are Means \pm standard deviations of triplicate determinations. Values in each row with different superscript letters differ significantly at $5 \%$ level $(P<0.05)$

Table 11: Packed cell volume (\%) of rats fed with Amarantus hybridus grown on crude oil post-remediated soil.

\begin{tabular}{|l|l|l|l|}
\hline & Control soil & $\begin{array}{l}\text { Natural } \\
\text { attenuated soil }\end{array}$ & Bioaugmented soil \\
\hline Weanling male & $10.33 \pm 0.34^{\mathrm{a}}$ & $7.78 \pm 0.51^{\mathrm{bc}}$ & $7.22 \pm 0.39^{\mathrm{bc}}$ \\
\hline Weanling female & $10.55 \pm 0.69^{\mathrm{a}}$ & $8.23 \pm 0.69^{\mathrm{bc}}$ & $7.92 \pm 0.75^{\mathrm{bc}}$ \\
\hline Adult male & $11.55 \pm 0.84^{\mathrm{a}}$ & $8.44 \pm 0.20^{\mathrm{bc}}$ & $7.89 \pm 0.84^{\mathrm{bc}}$ \\
\hline Adult female & $11.07 \pm 0.58^{\mathrm{a}}$ & $8.22 \pm 0.84^{\mathrm{bc}}$ & $7.44 \pm 0.51^{\mathrm{bc}}$ \\
\hline
\end{tabular}

Values are Means \pm standard deviations of triplicate determinations. Values in each row with different superscript letters differ significantly at $5 \%$ level $(P<0.05)$.

Table 12: Haemoglobin concentration $\left(\mathrm{gdl}^{-1}\right)$ of rats fed with Amarantus hybridus grown on crude oil post-remediated soil.

\section{References}

1. Sposito G (2008) The chemistry of soils. $2^{\text {nd }}$ Edition, Oxford University Press, London 37.

2. Van Hamme JD, Singh A, Ward OP (2003) Recent advances in petroleum microbiology. Microbiol Mol Biol Rev 67: 503-549.

3. Wong JW, Fang M, Zhao Z, Xing B (2004) Effect of surfactants on solubilization and degradation of phenanthrene under thermophilic conditions. J Environ Qual 33: 2015-2025.

4. Alexander M (1994) Biodegradation and bioremediation. Second Edition Academic Press, New York 692.

5. Ojumu T, Bello OO, Sonibare JO, Solomon BO (2004) Evaluation of microbial systems for bioremediation of petroleum refinery effluents in Nigeria. African $J$ Biotech 1:31-35

6. Gonza'Lez JL, Serrano A, Gallego M, Tejada M (2008) Natural attenuation of diesel aliphatic hydrocarbons in contaminated agricultural soil. J Environ Pollut 144: 203-209.

7. ljah UJJ, Antai SP (2003) The potential use of chicken-drop microorganisms for oil spill remediation. J Environ 23: 89-95.

8. Ohiri RC, Uwakwe AA, Onyeike EN (2012) pH variations and lipase activities of crude oil bioremediated agricultural soil. Int Jour Curr Res 4: 034-037.

9. Pond KL, Huang Y, Wang Y, Kulpa CF (2002) Hydrogen isotopic composition of individual n-alkanes as an intrinsic tracer for bioremediation and source identification of petroleum contamination. Environ Sci Technol 36: 724-728.

10. Siddiqui S, Adams WA (2002) The fate of diesel hydrocarbons in soils and their effect on the germination of perennial ryegrass. Environ Toxicol 17: 49-62

11. Hejazi RF, Husain T (2004) Landfarm performance under arid conditions. 2 Evaluation of parameters. Environ Sci Technol 38: 2457-2469.

12. Leaf (2011) Wikipedia, the free encyclopedia.

13. Nichols M, Hilmi M (2009) Growing vegetables for home and market. Rura Infrastructure and Agro-Industries Division, Food and Agriculture Organization (FAO) of the United Nations. Diversification booklet number 11: 19-40.

14. Wood AJ and Roger J (2000) A simple and non-destructive technique fo measuring plant growth and development. American Biology Teacher 62: 215217

15. Beale RN, Croft $D$ (1961) A sensitive method for the colourimetric determination of urea. J Clin Pathol 14: 418-424.

16. Slot C (1965) Plasma creatinine determination. A new and specific Jaffe reaction method. Scand J Clin Lab Invest 17: 381-387.

17. Hohenwallner W, Wimmer E, Sommer R (1979) [Determination of alphaamylase by an enzymatic kinetic method on the ABA-100 (author's transl)]. Clin Chem Clin Biochem 17: 349-352.

18. Kind PR, King EJ (1954) Estimation of plasma phosphatase by determination of hydrolysed phenol with amino-antipyrine. J Clin Pathol 7: 322-326.

19. Reitman S, Frankel S (1957) A colorimetric method for the determination of serum glutamic oxalacetic and glutamic pyruvic transaminases. Am J Clin Pathol 28: 56-63.

20. Corash L (1995) Laboratory haematology: Methods for the analysis of blood. In: Handin RI, Lux SE, Stossel TP (Eds) Blood: Principles and Practice of Haematology. J. B. Lippincott Company, Philadelphia USA. 
Citation: Onyeike EN, Ohiri RC, Uwakw AA (2014) Toxicological Parameters of Albino Rats Fed with Amarantus hybridus Grown on Crude Oil Postremediated Agricultural Soil. J Environ Anal Toxicol 4: 251. doi: 10.4172/2161-0525.1000251

Page 8 of 8

21. Conn HJ (1969) Biological Stains. In: Lillie RD (Ed) $8^{\text {th }}$ edition. Williams and Wilkins, Baltimore 269-281.

22. Duncan BD (1955) Multiple range and multiple $F$ test. Biometrics 11: 1-42.

23. Kipopoulou AM, Manoli E, Samara C (1999) Bioconcentration of polycyclic aromatic hydrocarbons in vegetables grown in an industrial area. Environ Pollut 106: 369-380.

24. Tao S, Cui YH, Xu FL, Li BG, Cao J, et al. (2004) Polycyclic aromatic hydrocarbons (PAHs) in agricultural soil and vegetables from Tianjin. Sci Total Environ 320: 11-24.

25. Chicarelli MI, Eckardt CB, Owen CR, Maxwell JR, Eglington G, et al. (1990) Application of inductivity coupled plasma mass spectrometry in the determination of organometallic compounds in chromatographic fractions from organic rich shales. J Organ Geochem 15: 267-274.

26. Meagher RB (2000) Phytoremediation of toxic elemental and organic pollutants. Curr Opin Plant Biol 3: 153-162.

27. Environment agency (2009c) Human health toxicological assessment of contaminants in soil. Science Report SC050021/SR2. Bristol, UK.

28. Baynes RE, Hodgson E (2004) Absorption and distribution of toxicants. In Hodgson E (Ed), A textbook of Modern Toxicology, $3^{\text {rd }}$ edition. John Wiley \& Sons Inc., USA 77-91.

29. Karri SK, Saper RB, Kales SN (2008) Lead encephalopathy due to traditional medicines. Curr Drug Saf 3: 54-59. 